\title{
Between the Labor Camp and the Clinic: Tema or the Shared Forms of Late Soviet Homosexual Subjectivities
}

\author{
Arthur Clech
}

\begin{abstract}
"We had to look out for each other for the very reason that we were outside the law; not criminals, but outside the law." The singer and lesbian writer, Olga Krauze, born in 1953, reflects on her Soviet homosexual subjectivity by invoking a rich "we," highlighting in the process some of the shared forms of subjectivity constructed by both women and men expressing their homosexual desire during the late Soviet period. ${ }^{2}$ If, in objective terms, only men could be imprisoned under anti-sodomy legislation, women could nevertheless, in subjective terms, experience the same. Women and men could share some forms of subjectivity in the face of hostility, stigmatization, and persecution of their same-sex desire. As Krauze explains, "Yes, for 'the men' there was the (anti-sodomy) law, which was the reason why so many marriages between lesbians and gays took place. We protected each other, looked out for each other. ${ }^{3 "}$ By listening attentively to the words of these women and men, we may gain an understanding of Soviet homosexual subjectivities, the contours of which were not always sharply defined but which attested to a common set of resources that individuals used to render themselves the subjects of their homosexuality.
\end{abstract}

I wish to thank the CEFR (Centre d'Études Franco-Russe de Moscou) for funding three research missions and part of the translation of this article, and for the scholarly support provided by its researchers, particularly Jean Radvanyi, Juliette Cadiot, Hélène Mélat, and Masha Cerovic. The article was presented at the Soviet history seminar held jointly by the CEFR and DHI (Deutsche Historische Institut) Moscow, for which I am grateful. I would also like to thank Harriet L. Murav, Richard Mole, and the anonymous reviewers for Slavic Review for their very helpful and constructive comments on the original manuscript. I am also in debt to Alain Blum, my research director at EHESS (CERCEC) (École des hautes études en sciences sociales, Centre d'études des mondes russe, caucasien et centre-européen), and to Irina Roldugina, Brendan McElmeel, Juliette Rennes, Ivan Chupin, Anna Åberg, Régis Schlagdenhauffen, Lina Tsrimova, Grégory Dufaut, Amandine Regamey, Mona Claro, Rose-Marie Lagrave, and Fabien Rothey for their re-reading and valuable advice. My field work gained enormously from crucial friendly support from Elena Grigorievna Gusyatinskaya, Igor Jasin, Olga Krauze, Nikolaj Baev, Ol'ga Gert (pseudonym), Pavel Samburov, Valery Sozaev, and many others I prefer not to cite by name.

1. Interview with Olga Krauze, Moscow, July 2014. I give invented male and female first names. The only cities I identify are Moscow and St. Petersburg. Olga Krauze and Nikolaï Baev, however, insisted on not being anonymized.

2. My sample size does not allow me to adequately address the 1950s. However, it is possible to take the new Soviet penal code of 1960 to mark the beginning of the late Soviet period. Designed to put an end to the Stalinist era, it ratifies the 1955 authorization of abortion while distancing itself from the penal codes of the popular Republics of Czechoslovakia and Hungary in not decriminalizing homosexuality. Thus, I understand the later Soviet period to begin in 1960 and end in the second half of the 1980s, extending in some areas, where the effects of perestroika were not immediately evident, until the end of the 1980s.

3. Interview with Olga Krauze, Moscow, July 2014. 
On the basis of in-depth interviews I conducted with thirty-six men and women who lived and expressed their same-sex desire in the late Soviet period, the aim of this article is to examine the forms that Soviet homosexual subjectivities took, the ways in which some of these forms were shared by women and men in the late Soviet period, and what made these homosexual subjectivities uniquely Soviet. This shared horizon, which can be brought out through a study of homosexual subjectivities, calls into question the oversimplified dichotomy proposed by Masha Gessen, which has for the most part remained uncontested in the academic literature on samesex desire in the USSR; namely, that male homosexuality was penalized (sodomy being a legal offence) while women were subject to psychiatric intervention. ${ }^{4}$ My interviewees attest to a more fluid reality: men were also subject to the psycho-pathologization of their homosexuality, just as women feared the article penalizing male homosexuality.

As Francesca Stella explains: "While punitive and stigmatizing discourses circulated, the categories 'homosexual' and 'lesbian' remained unavailable as affirmative narratives of social identity for most of the Soviet period." ${ }^{5}$ In parallel, as Heller points out, "gay and lesbian identities have no formal history of existence in Russia as in the West." 6 This lack of a shared identity has led certain western scholars, such as Daniel P. Schluter, to deny the existence of any sense of community among Soviet homosexuals. ${ }^{7}$ The "fraternity" that Schluter instead ascribes to Soviet homosexuals is seen as different fromand less developed than-the American gay and lesbian "community," as if the former were some earlier stage in "global gay" consciousness. ${ }^{8}$ I concur

4. A 1934 law introduced under Stalin stipulated five years' imprisonment for sodomy between men and was not repealed until 1993. Women's same-sex desire at that time might be defined as "sluggishly manifesting schizophrenia" (vialotekushchaia shizofreniia), a "uniquely Soviet term," or "transsexualism" by Soviet psychiatrists, who could order a psychiatric internment or propose a change in gender identity. See: Laurie Essig, Queer in Russia: A Story of Sex, Self and the Other (Durham, NC, 1999), 28. Not until 1999 was homosexuality withdrawn from the list of psychiatric disorders. Medico-legal discourse divided homosexuality in gender terms, with men seen as subjects before the law, since they were responsible for their actions, while women were not: their homosexual desire could be subject to therapeutic intervention by the medical authorities. See: Essig, Queer in Russia, 28, 36-38; Masha Gessen, The Rights of Lesbians and Gay Men in the Russian Federation: An International Gay and Lesbian Human Rights Commission Report (San Francisco, 1994); and Dan Healey, Homosexual Desire in Revolutionary Russia: The Regulation of Sexual and Gender Dissent (Chicago, 2001). It should be stressed that this notion of "sluggishly manifesting schizophrenia" (vialotekushchaia shizofreniia) is employed against a plurality of dissidents, not only against those who think differently (inakomysliashchie), but also against those who feel differently (inakochuvstvuiushchie).

5. Francesca Stella, "Lesbian identities and Everyday Space in Contemporary Urban Russia” (PhD diss., University of Glasgow, 2009), 134.

6. Dana Heller, "t.A.T.u. you! Russia, the Global Politics of Eurovision, and Lesbian Pop,” Popular Music 26, no. 2, (May 2007): 197; see also Essig, Queer in Russia and Healey, Homosexual Desire in Revolutionary Russia.

7. Daniel P. Schluter, Gay Life In The Former USSR: Fraternity Without Community (New York, 2002), 6.

8. Martel, Frédéric. Global Gay: How Gay Culture is Changing the World, Cambridge, Mass., 2018. See also Dennis Altman, "Global Gaze/ Global Gays," GLQ: A Journal of Lesbian and Gay Studies 3, no. 4, (May 1997): 417-36. On the notion of community, 
that there was no visible community and consequently no social identity; yet we must look beyond this: despite the absence of a homosexual identity or community, it is nevertheless possible to bring out forms common to the homosexual subjectivities that emerged in the USSR. To this end, I examine first the significance of the confrontation with stigmatization as a shared point of reference for men and women in the construction of their homosexual subjectivities. Second, I describe how these subjectivities were shaped through common forms such as language, irony, and solidarity, while at the same time tracing the limits of such commonality. These subjectivities can be shown to adopt Soviet values, while seeking to go beyond their gender categorizations. Indeed, national, cultural and political forms interact within complex subjectivities all the more, given the antagonistic relation towards Soviet identity that they share.

\section{Concepts and Methods}

An open definition of subjectivity, or "the forms through which the individual is called to become a subject," would appear necessary. ${ }^{9}$ To seek to identify in a fixed and circumscribed manner what does or does not belong to subjectivity would be to forget that the diversity of forms which subjectivity can assume is fundamental to the very core of the concept. One such form is the discursive practice of self-expression, undertaken by the participants in my interviews who, in speaking about themselves, communicated to me their experience as homosexuals. We must accordingly orient ourselves towards a notion of homosexual subjectivity that is wider in scope than that of homosexual identity: it may include, but cannot be reduced to, this identity. In effect, homosexual identity is only one of the possible forms through which individuals in their experience of homosexual desire can render themselves the subject of their homosexuality, in this instance by feeling a part of a positive collective identity. One of these, Soviet identity, does not allow for homosexual identity. In contradistinction to national identity (natsional'nost'), it constituted a political subjectivity, an idea of citizenship. Given that the men and the women who recounted their life stories to me had been called upon to constitute themselves as Soviet subjects since their childhood, they had to forge their homosexual subjectivities in confrontation with

Stephen O. Murray notes: "There are no clear-cut criteria with which to decide whether there is a "community." Concerning North America before the Stonewall riots of 1969, the sociologist asserts: "So long as there were only friendship networks of homosexually-inclined men or women and systems of delivering sex, it was possible to argue there was not a 'community,"” see Stephen O. Murray “The Institutional Elaboration of a Quasi-ethnic Community," International Review of Modern Sociology 9, no. 2 (July-December 1979): 165-77.

9. Pierre Guenancia, "Foucault / Descartes: la question de la subjectivité," Archives de Philosophie 65, no. 2 (2002): 241. We should indeed note, following Frédéric Gros, that "the problem of the subject, of subjectivity, indeed of the self in Foucault is one of the most complex ... that concepts such as subjectification, practice of self, and self-relation are markedly underdefined in and for themselves and are perhaps more to be understood as frames of reference for the interpretation of historical phenomenon than as concepts to be explored in strict autonomy from a philosophical perspective proper," see Frédéric Gros, "Sujet moral et soi éthique chez Foucault," Archives de Philosophie 65, no. 2 (2002): 229-37. 
a Soviet identity that closed off the possibility of sexual alterity. This essentially antagonistic relation should not, however, be viewed in exclusively negative terms. The work of the historian consists in bringing out the positivity of the forms which homosexual subjectivity may assume, while considering the difficulties that it encounters in coming to expression. The task therefore is to show how this Soviet identity was re-appropriated through the construction of original homosexual subjectivities. ${ }^{10}$ Hemmed in by greater constraints than other Soviet citizens, they developed a homosexual subjectivity, mostly living it outside labor camps and psychiatric hospitals. ${ }^{11}$

The question of how we should designate the expression of "non-normative" sexual desire in the Soviet and Russian context has been the subject of much academic debate. While the term "non-heterosexual" has been used by scholars such as Francesca Stella, a term designed to show respect towards the way in which the women she interviewed might describe themselves, I prefer "individuals expressing same-sex desire," the formula used by Dan Healey in his history of Soviet homophobia, as this better avoids the risk of exerting symbolic violence. ${ }^{12}$ Individuals did not necessarily want to be identified according to their sexual orientation by experts whose power, and symbolic violence, is also present in the words they use. In her Queer in Russia, Laurie Essig specifically noted the existence of queer sexual subjectivities in Russia in the early 1990s, emerging from out of the dislocation of fixed Soviet sexual identities, which offer a contrast to the stable identities widely claimed to have existed in the United States. This conceptual leap made it possible to appreciate the novelty of "queer" subjectivities in Russia that do not involve an $a$ priori allocation of identities to individuals. ${ }^{13}$

10. My approach owes much to Alexei Yurchak, who shows both how the regime in practice encouraged the formation of new subjectivities and also how individuals selectively incorporated the values espoused by official discourse, thus cultivating a feeling of belonging to a Soviet collective identity that was far less uniform than it appeared, see Alexei Yurchak, Everything Was Forever, Until It Was No More: The Last Soviet Generation (Princeton, 2006).

11. A minimum sentence for consenting relations was set at three years in 1934 to make sure homosexuals were sent to labor camps rather than ordinary prisons. This minimum sentence was then removed in 1961, see Healey, Homosexual Desire in Revolutionary Russia, 227.

12. Francesca Stella, "The Language of Intersectionality: Researching 'Lesbian' Identity in Urban Russia,” in Yvette Taylor, Sally Hines, and Marke E. Casey, eds., Theorizing Intersectionality and Sexuality (New York, 2010), 2; Healey, Homosexual Desire in Revolutionary Russia.

13. Her attempt to write a "history of Russian sexuality" as distinct from that of western countries has, however, been criticized for its "exceptionalism." Quoting Leo Bersani, Brian James Baer argues that queer approaches such as hers tend to "erase[s] gay and lesbian subjects," see Leo Bersani, Homos (Cambridge, MA, 1996): 31-76, cited in Brian James Baer, Other Russias: Homosexuality and the Crisis of Post-Soviet Identity (New York, 2009), 160. For my part, I would argue that appreciating the importance of subjectivities, in whatever form they might be, requires not only that we provide theoretical justification but also base ourselves on the speech of interviewees so that "sexual alterity" may be represented by "self-speaking subjects," see Essig, Queer in Russia, 84. For an introduction to subjectivities in the USSR, some key references are Malte Griesse, "Soviet Subjectivities: Discourse, Self-Criticism, Imposture," Kritika: Explorations in Russian and Eurasian History 9, no. 3 (Summer 2008): 609-24; and Anatoly Pinsky, "Soviet Modernity 
While Stella, unlike Essig, elects not to focus "more narrowly on identity and subjectivities," we can see the benefit of examining subjectivities by looking at two similar testimonies. ${ }^{14}$ These are the testimonies of Julia, reported by Stella, and Tatiana, reported by Alisa Zhabenko, to show how during the eighties, the "comrades' courts" treated female homosexuality without recourse to either law or medicine. ${ }^{15}$ In both cases, non-professional tribunals, established to try minor offenses and staffed by volunteers, not only handed down moral condemnation of "morally corrupt behavior" (moralnoe razlozheniie) and an "immoral lifestyle" (amoral'nyi obraz zhizni), but also issued orders to "shun" (boikotirovat') the condemned individuals. While Tatiana reports that she made new friends while undergoing this process, Stella reports that the two women caught having sexual relations in her case broke off all relations with each other. From a Foucauldian point of view, Stella seeks primarily to show that the regulation of sexuality does not necessarily involve state violence, which in this case would have meant the women's internment in a psychiatric hospital. As her work does not substantively address the question of subjectivity in her consideration of this case, we cannot understand why one of the women is nevertheless horrified at the idea of "going to jail" for "that," when there was no law against homosexual behavior between women, as her partner points out. ${ }^{16}$ Stella's work does not therefore explain "how people, in order to make their behavior comprehensible, identify themselves by connecting with other people-the homosexual men who risked imprisonment in the USSR-in a relationship which they find relevant." ${ }^{17}$ In my article, I thus seek to show how some women expressing same-sex desire linked their fate to that of homosexual men in a bid to make sense of their homosexual subjectivity.

Because "it seemed necessary to close off the entire topic of gay subjectivity to respectable inquiry, so as to prevent gayness from ever again being understood as a sickness," queer studies has for a long time been "silent" on this topic. ${ }^{18}$ David Halperin, a historian of homosexuality and theorist of queer studies, attributes this silence to the theoretical heritage of Michel Foucault. While Foucault readily concedes to individuals the capacity to engage in a process of self-shaping, and outlines the possibilities open to individuals for the interpretation of their own experience to this end, he also shows how

Post-Stalin: The State, Emotions, and Subjectivities," Kritika: Explorations in Russian and Eurasian History 16, no. 2 (Spring 2015): 395-411.

14. Francesca Stella, Lesbian Lives in Soviet and Post-Soviet Russia: Post/socialism and Gendered Sexualities (New York, 2015), 135.

15. Stella, Lesbian Lives in Soviet and Post-Soviet Russia, 50. Alisa Zhabenko, "Lesbiianstva ne bylo!': nelegitimnyi gendernyi kontrakt v Sovetskoi Rossii," in Konstruiruia "sovetskoe"? Politicheskoe soznanie, povsednevnye praktiki, novye identichnosti: materialy nauchnoi konferentsii studentovi aspirantov (14-15 Aprelia 2011 goda) (St. Petersburg, 2011), 89.

16. Francesca Stella, "Issledovanie zhizni lesbiianok v sovetskii period: Pokolencheskii podkhod," in Aleksandr Kondakov ed., Na pereput'e: Metodologiia, teoriia $i$ praktika LGBT $i$ kvir issledovanii (St. Petersburg, 2014), 239.

17. Luc Boltanski and Laurent Thévenot, De la justification: les économies de la grandeur (Paris, Gallimard, 1991), 15.

18. David M. Halperin, What Do Gay Men Want?: An Essay on Sex, Risk, and Subjectivity (Ann Arbor, MI, 2007), 3. 
subjectification has come to stand in for the more directly repressive process of subjugation. ${ }^{19}$ When Foucault writes of "the truth regarding sex in the West," he omits the Soviet Union. ${ }^{20}$ In compensating for this omission, we should not underestimate the effect produced by Soviet medical and penal discourse on the subjectification of individuals who experienced homosexual desire; nor should we forget to bring out, while taking account of the latter, the room to manoeuver open to individuals for constructing from their experience the subject of their sexuality. ${ }^{21}$

My research therefore seeks to challenge established understandings of the relationship between male and female homosexuals: "Male domination and power inequalities between genders are often revealed as distinct ways of constructing oneself as a lesbian, if one is a woman, or as gay, if one is a man..$^{22}$ The sociology of homosexuality consists in noting the contrasts between male and female homosexuality, despite the strategic attempts made to unite them into a single political community." ${ }^{23}$ The realities of my fieldwork contradict this imperative. I first met women of the last Soviet generation through a French lesbian friend, who made me aware of the existence of

19. The Will to Knowledge is essential for understanding how in the west discourses on sex, far from being repressed, are encouraged to proliferate all the more within a new dispositive of power in large part nourished by psychiatry. The "scienta sexualis" constituted "sexuality" as an object of study in which the truth of individuality is to be found in discourse on sex. No longer a "subject" to be "subjugated," from the nineteenth century onwards, the "individual" is issued the directive of interiorizing discourse on sexuality within the framework of a process of subjectification across which individuals constitute themselves as subjects, see Michel Foucault, The History of Sexuality. Volume 1: An Introduction, trans. Robert Hurley (New York, 1978).

20. For a Foucauldian history of homosexuality in Russia see: Laura Engelstein, The Keys to Happiness: Sex and the Search for Modernity in Fin-de-Siècle Russia (Ithaca, 1992); Healey, Homosexual Desire in Revolutionary Russia; and Essig, Queer in Russia. Dan Healey's Foucauldian approach in his history of homosexuality from 1870 to World War II is the reference monograph, crucial for any socio-historical approach to homosexuality in Russia, although it does not give enough space to the expression of homosexual subjectivities, see Arthur Clech, "Istoriografiia russkoi gomoseksualnosti do i posle Oktiabrskoi revoliutsii: Razlichnye podkhody i perspektivy," [Historiography of Russian homosexuality before and after the October revolution: different approaches and research perspectives], Kak my pishem istoriiu eds. Grégory Dufaud, Guillaume Garreta, Liudmila Pimenova, trans. E. I. Balakhoskoi, E.V. Dvornichenko, and L.A. Pimenovoi (Moscow, 2013), 335-75. In a recent article, Ira Roldugina fills the lacuna while drawing on extensive archival research. See: Irina Roldugina, “'Pochemu my takie liudi?' Rannesovetskie gomoseksualy ot pervogo litsa: Novye istochniki po istorii gomoseksual'nykh identichnostei v Rossii” [“'Why Are We Such People?' Early Soviet Homosexuals Speaking in the First Person: New Sources on the History of Homosexual Identities in Russia"], Ab Imperio 2 (2016): 183-216. In his last monograph, Dan Healey paid more attention to subjectivities. See his Russian Homophobia From Stalin To Sochi (New York, 2018).

21. "When one defines the exercise of power as a mode of action upon the actions of others, when one characterizes these actions as the government of men by other men-in the broadest sense of the term-one includes an important element: freedom." See: Michel Foucault, "The Subject and Power" in Power, ed. James D. Faubion, trans. Robert Hurley and others. (New York, 2000): 341-42.

22. Adrienne Rich, Compulsory Heterosexuality and Lesbian Existence (London, 1981) and Bersani, Homos.

23. Sébastien Chauvin and Arnaud Lerche, Sociologie de l'homosexualité (Paris, 2013), 4. 
the gay and lesbian archives in Moscow in 2006. Some of these women, who expressed their same-sex desire in the late Soviet period, recommended their male homosexual friends to me, thereby indicating that a mixed-homosexual social world did indeed exist in Moscow. Starting from the ethnographical principle that the object of research should take shape through fieldwork that questions rather than allows itself to be determined by theoretical imperatives, I listened to these women and men and identified points of convergence. In the process, it became clear that some of these women and men had become the subjects of their homosexuality by attempting to go beyond gender categorizations. My research has persuaded me that speaking of subjectivities in the plural does not necessarily involve categorizing them differentially in terms of their gender and "nationality" (natsional'nost'); on the contrary, gendered and national dimensions would appear to interact within complex homosexual subjectivities. We may indeed bring out common forms of homosexual subjectivities that emerge from the accounts of participants by following the indications they give towards a shared self-understanding in communicating how they lived, felt, and understood their homosexual desire. This shared horizon finds succinct expression in a term of self-designation: tema (literally "theme"). This term, in the singular, designates all persons with whom a given individual may feel they share forms common to homosexual subjectivities. The word tema has the virtue of condensing within a single word a certain affinity transcending gender, nationality, and social status affiliations. Making the difficult transition into theoretical terms, it may serve as a frame of reference for forms shared by Soviet homosexual subjectivities. I will here limit my study of the latter to the European region of the Russian Soviet Federative Socialist Republic in the late Soviet period. ${ }^{24}$

The subjectivities that are at the heart of my interrogation can sometimes challenge the "acquired ignorance" of the late Soviet period, which might be termed "gender conventionalism," or "support for the gender roles that are perceived as natural, normal, 'traditional,' irrespective of their actual historical roots in Russian society; and a general aversion against revising or reflecting on these gender roles." ${ }^{25}$ Recognizing the differences-but also the similarities-between Soviet men and women who expressed same-sex desire, and showing how men and women adopted and resisted Soviet gender norms, is an important part of my research. In this endeavor, I am influenced by the work of Francesca Stella, whose ethnographic research closely analyzed the experience and behavior of women who expressed same-sex desire in the late Soviet period. She describes the biographies of "non-heterosexuals" heavily dependent on the gendered assignments to marriage and motherhood, which they may adopt without necessarily perceiving them as alienating.

24. The bind between "nationality" (natsional'nost'), Soviet citizenship and sexuality is the subject of a French publication which gives a major place to fieldwork carried out in Georgia in 2015 and 2016. See: Arthur Clech, "Des subjectivités homosexuelles dans une URSS multinationale,” Le mouvement social 260 (July-September 2017), 91-110.

25. Anna Rotkirch, The Man Question: Loves and Lives in Late 20th Century Russia (Helsinki, 2000): 132-33. 
I carried out unstructured interviews, within the framework of an ethnographic immersion in Moscow $(2010,2011){ }^{26}$ I carried out semi-structured interviews in St. Petersburg and in two cities of more than 500,000 inhabitants located in the central region of European Russia $(2011,2015,2016)$ belonging to the Red Belt (krasnyii poias). ${ }^{27}$

For the interviews, which took place in Russian and were of at least two hours duration, I was able to meet on at least three, if not more, occasions with thirty-six individuals who had become aware of their homosexual desire in the USSR: twenty-one women and fifteen men, half of whom had lived all or part of their lives outside of Moscow and Leningrad; thirteen had been born between 1938 and 1960 and twenty-three between 1961 and 1978. The two later Soviet cohorts shared strong social ties, participants from one cohort suggesting that I get in contact with participants from the other. They had for the most part pursued studies in higher education, and while identifying them as part of an educated "middle class" is of little value in the Soviet context, two thirds of the participants identified themselves as belonging to the "intelligentsia."

While analyzing my own interview data, the oral histories of men and women expressing same-sex desire undertaken by the Slavist Sonja Franeta in the 1990 s served as a key point of reference. ${ }^{28}$ The sociologist Anna Rotkirch's work with biographical accounts from the late Soviet period convinced me of the value of working with such sources in that they allow their authors to speak freely. Naturally, the written accounts collated by Rotkirch as well as Olga Krauze's biography are more formal than the oral testimonies I collected in my interviews; the former were produced over a longer time-frame and were more thoughtful and less spontaneous. ${ }^{29}$ Where possible, I place the oral and written accounts of the same person together to illustrate the constructed nature of these Soviet homosexual subjectivities. Since I did not seek to force any sexual identity on my respondents, I applied consciously the same rule to myself. ${ }^{30}$

26. From the beginning of my first field trip to Moscow (2010-2011), I frequently consulted the private gay and lesbian archives. Indeed, I offered my services as a volunteer by scanning a portion of its database. These archives have the additional function of offering an important place of social gathering for women born before the seventies. I regularly took part in the activities of an informal group, the "Rainbow" association, which is now a member of ILGA-Europe, the European Region of the International Lesbian and Gay Association. I also attended a support group run by gays (and a lesbian) which then held weekly meetings in the HIV screening center Jasen'.

27. Given that the majority of doctoral students are not financed in France, a measure of tolerance is shown over the formal requirements concerning the duration of research.

28. Sonja Franeta, Rozovye Flamingo: 10 Sibirskikh Interv' iu (Tver, 2004).

29. Olga Krauze gave me two interviews in January 2010 and July 2014. She wrote an autobiographical text that was published in 2009. I only read it after the interviews. See Olga Krauze, Otpetaia zhizn' (Tver, 2009).

30. For my part, I thought it best not to shape the perception of my interviewees. I elected to maintain a heuristic ambiguity concerning my own self-presentation given that it seemed to be the sincerest attitude to adopt and to be an authentic expression of the questioning of my own subjectivity. In addition, it seemed to me that this ambiguity allowed for a variable investment on the behalf of my interviewees. It was important to minimize the influence of my own presentation of self on their representations, and it was 


\section{Stigmatization and the Production of Shared Subjectivities}

In the "conspiracy of silence" that surrounded the question of homosexuality, any person who realized that their desires diverged from those of their fellows might look to written sources for information that would provide an escape from existential isolation. ${ }^{31}$ The reality that the written word embodied thereby became an authority. As a case in point, the Penal Code of the Russian Soviet Federative Socialist Republic paradoxically attested to the existence of homosexuality, male only, by condemning sodomy (muzhelozhstvo) between consenting adults under Article 121 of the 1960 Code. The third edition of the Great Soviet Encyclopaedia (1969-1978) contains an article entitled Gomoseksualism with a two-part definition: an ideological, criminalizing section that falsely states that homosexuality is not punishable by law in most capitalist countries but is in Socialist countries, and a pathologizing section in which homosexuality is described as a sickness "found among people of both sexes." This article references another article, on muzhelozhstvo, which removes any doubt that punishment only concerns men. ${ }^{32}$

\section{Female Homosexuality as Considered Outside the Law (vne zakona)}

The ambiguity of the wording and the general lack of information helped to expose female homosexuality to suspicion. According to Nadezhda, born in 1955, some women of her age, including her ex-girlfriend who worked for the police in the Urals, were convinced at the time that the USSR criminal article

essential that participants should not be compelled by a normative, in particular heteronormative, injunction emanating from me. They were not to feel obliged to say who they were. Most of my respondents assumed that I was homosexual, and I did not think of contradicting them; a minority, meanwhile, whom I knew personally, realized that I might not wish to define myself with any sexual identity at all. The question of this self-presentation of sexual identity never arose explicitly in my interviews with people who had expressed their same-sex desire in the USSR, because the way in which they re/presented themselves and their past borrowed little, and at most in anachronistic fashion, from the vocabulary of their sexual identity. As I was being entrusted with their life stories, I was well aware that as a male, a French national, and an academic, without Russian heritage, I had to make a special effort not to exert any symbolic violence. Naturally the way in which my respondents recounted their stories was necessarily influenced by how I might appear to my respondents; yet as a Slavist who has spent eight years in the post-Soviet world since 2004, it was my national identity that was explicitly questioned, because of my unusual Russian accent, rather than my gender or sexual identity.

31. "Thirty years under the reign of a conspiracy of silence naturally led to an incredible level of ignorance concerning sexuality. Soviet children and adolescents in the 1950s to 1970 s did not even know the most basic facts of the matter." See: Igor' Semenovich Kon, Seksual'naia kul'tura $v$ Rossii: Klubnichka na berezke (Moscow, 1997), 184. This quotation, as with all the others taken from the original Russian, unless otherwise stated, is retranslated into English from the author's own French version.

32. This last statement is untrue because the German Paragraph 175 criminalizing homosexuality was repealed in the GDR in 1968, one year before the Federal Republic. Similar laws were abolished in Czechoslovakia and Hungary in 1961, and in Bulgaria in 1968. In Communist Poland, there was no explicit criminalization of homosexuality whether male or female. 
concerned them as well. ${ }^{33}$ This confusion was also reflected in everyday language. Olga Krauze, born in 1953, speaks of her wish to know more about her desires and the discovery she made as a teenager of the term lesbiianka in a psychiatric textbook: "I found a textbook of psychiatry in which I met for the first time the term lesbiianka, women's sodomy (zhenskoe muzhelozhstvo)." ${ }^{34}$

Either way, the mere realization that there was an article of law making homosexuality punishable, even between men, caused real anxiety. Polina, born in 1958, did her best to make her homosexuality totally invisible in public after hearing from a friend about Article 121: "When I learned there was a law against homosexuality, I got frightened . . . I got frightened [long silence], I was afraid of losing my job. I didn't want anyone at work to know. Straightaway ... hearing then that it was criminal ... I just didn't want [laughs] to get mixed up in it all. No . . . it's my way of life . . . I didn't think it was criminal."35

The criminalization of male homosexuality was a symbolic threat to women expressing their same-sex desire; it scared them. It also drove women to forge homosexual subjectivities with forms in common with those of men, appealing to insider knowledge that contradicted medicolegal discourse. One element of this knowledge was the act of generalization to which they perceived themselves subject: women expressing same-sex desire realized that it was not so much a specific sexual practice-sodomy-that was targeted by the law as homosexuality itself, an awareness which led to the self-censoring of behavior in public spaces: “Well, yes, let's say I wasn't afraid before . . . no one reacted. My girlfriend and I could eat out in a restaurant, I could put my arms round her ... but then I started to be afraid. ... I stopped myself from putting my arms round her. ${ }^{36}$ " Liudmila, born in 1972, knew nothing of homosexuality until the age of 14 when she had her first love affair with a girl of her own age. One day she and her girlfriend saw a group of men being arrested on a beach in the Moscow suburbs. ${ }^{37}$ She noticed that one of them was a sports coach from her summer camp, so she and her friend called to him by name and thus saved him from the police. She recalled what he said to them on the way back to the camp: "If you want to take this path and if you are in love (at that point Katia and I knew what it was about, and Katia and I were in love), if you want to live that life, it will be very hard. No one will help you. You can only count on yourselves." ${ }^{38}$ Even allowing for the filtering process of memory, we should not overlook the significance of the fact that, as she recounts, it was by meeting a homosexual man that she gained knowledge about homosexuality.

33. Nadezhda, interview, Saint Petersburg, October 2016. Laurie Essig mentions that they could be stopped by the police: "many women told me of threats from the internal security apparatus as well as the KGB: if the women did not 'cooperate' they would be outed to their families, at their place of employment, to their neighbors," see Essig, Queer in Russia, 29.

34. Olga Krauze, interview, Moscow, July 2014.

35. Polina, interview, Moscow, June 2014.

36. Ibid.

37. Chistyi Zaliv nudist beach near Serebrianyi Bor. Liudmila, interview, Moscow, May 2014. According to an interview in May 2011 with a man born in 1938, this beach has been, since at least the 1970s, one of the few unvarying locations in Moscow's gay subculture.

38. Polina, interview, Moscow, June 2014. 
The criminalization of homosexuality did not leave women who expressed their homosexual desire in the USSR untouched, since it remained a major reference point with respect to which they constructed their subjectivities.

It is the ambiguity of the status of female homosexuality, and the key reference point which male homosexuality constituted, which led Olga Krauze to designate her perception of homosexuality and her understanding of herself as "outside the law." The Russian language distinguishes between what is actually criminal (prestupnoe) from what is outside the law (vne zakona). In other words, male homosexual relations were clearly prima facie criminal, while female homosexuality was only socially reprehensible, although indicating a predisposition towards crime. Franeta's interviews show how much the association of these women with the penal system was indeed part of one Soviet representation of female homosexuality. Sacha, aged 20, said: “I didn't consider myself a lesbian because I thought that all lesbians were in prison." 39 Sergei, born in Tomsk in 1951, told Franeta that a friend of his mother's in a labor camp was a lesbian: "I learned afterwards that she was a lesbian, although she never openly said so. All her life she was single, wore trousers and smoked strong cigarettes (papirosy). She always had men's jobs." ${ }^{40}$ It was in the world of the gulag that a particular image of the lesbian was to some extent visible in the USSR. While ignorance or misunderstanding of the law encouraged identifications that gave rise to some common forms of homosexual subjectivities, knowledge of the law itself did not prevent the emergence of such forms: even if it was not a crime, female homosexuality was perceived as being outside the law and lesbians as belonging to the imagined world of the labor camp. ${ }^{41}$ It is not an exaggeration to say, therefore, that some women who expressed their homosexual desire in the late Soviet period under perestroika arrived at an understanding of themselves in confrontation with the criminal-

39. Franeta, Rozovye Flamingo, 140. Interview, Krasnoiarsk, 1992.

40. Franeta, 100. Interview, Tomsk, 1995.

41. In one pioneering work, art historian and activist Olga Zhuk asserts, based on the memoirs of political detainees from the 1930s to the late 1970s, that the origin of the lesbian subculture in Russia in the 1990s lies in the Gulag. Quoting eye witnesses, she documents the authorities' aversion to homosexuality, which they associated with common criminality. As a member of the St. Petersburg intelligentsia, she idealizes the prerevolutionary lesbian subculture of the salons to amplify her scorn for the homosexual subculture of the labor camp. The Israeli sociologist of Russian origin, Adi Kunstman, draws on Olga Zhuk's research in her explanation of this distaste for homosexuality. Such distaste actually served as a social marker for political prisoners who sought to distinguish themselves through their cultural baggage. Openness about homosexuality was possible only in the camps. Between men or between women, it was seen as morally and aesthetically degrading and associated with the lumpenproletariat or common people. Prior to de-Stalinization, political prisoners were still held together with common criminals, and were introduced to their world. To prove that they had nothing in common with people of that sort, who were portrayed as animals or monsters, they had to demonstrate their moral and aesthetic superiority, making any public show of sexuality impossible. They had to protect themselves from a "vice," the first violence of which was its visibility considered as a force of corruption, or even a threat to their identity. See: Olga Zhuk, Russkie amazonki: Istoriia lesbiiskoi subkul'tury Rossii, XX vek (Moscow, 1998); Adi Kuntsman, “'With a Shade of Disgust': Affective Politics of Sexuality and Class in Memoirs of the Stalinist Gulag,” Slavic Review 68, no. 2 (Summer 2009): 308-28. 
ization of homosexuality. Like the men expressing homosexual desire at that time, these women also saw themselves in the light of the criminalization of homosexuality.

\section{The Psycho-pathologizing Definition of Homosexuality Reappropriated in Avoidance Strategies}

Women and men might become conscious of their homosexual desire not only through learning about the anti-sodomy law but also because of the pathologization to which their desire was subject if found out. Half the women I interviewed said that at least one of their friends or acquaintances had been sent to an asylum. ${ }^{42} \mathrm{~A}$ family member could request that such an action be taken, and neighbors too were a threat; the residence neighbors of a Leningrad technical college female student directly contacted the psychiatric hospital to have some young students taken there. ${ }^{43} \mathrm{~A}$ key aspect of this dynamic of psychopathologization was that these women were accused of threatening the health of society. Homosexuality was considered not only to be a sickness but also a perversion. In other words, the perverted person was liable to pervert others, in this case contaminate other women, following the widespread idea that it was possible to make someone homosexual as if by contagion.

The psychiatric hospital was assigned a prophylactic function as well as a rehabilitatory one, not so different from the function exercised by Soviet labor camps. Indeed, hospital and labor camps were sometimes confused, as Franeta records. In 2015, she described an interview she held in the summer of 1995 with Oleg Kuzmich Raspopov (1941-1997), living outside Novosibirsk. ${ }^{44}$ Raspopov was twice sentenced to hard labor under both Article 121 (sodomy) and Article 120 ("perverse assault on minors," aged fourteen, fifteen, and sixteen). From 1979 to 1984, he arranged to be interned in a psychiatric hospital to escape the camps. Unexpectedly, this turned out to be the most painful period: "I went to that hospital, but I curse that hospital-it would have been better for me in the camp.... They smash your head with a bowl and then rape you." 45 His testimony provides a vivid illustration of how, according to Raspopov, there were no degrees of repression: that psychiatric internment could be as bad as, if not worse than, imprisonment. Nevertheless, psychiatric internment was preferred to incarceration, which everyone sought to avoid. ${ }^{46}$ The accounts of the three men presented below described such strategies of

42. I was not myself able to find any women who had spent time in a psychiatric hospital for their homosexuality.

43. Olga Krauze, interview, Moscow, July 2014.

44. Her account takes the form of a chapter, "Eighteen years in the Gulag: Kuzmich. . ." in Sonja Franeta, My Pink Road to Russia, Tales of Amazons, Peasants, and Queers (Oakland, CA, 2015): 201-31.

45. Ibid.

46. His experience was confirmed by someone eight years younger, Viktor, who avoided military service by using the psycho-pathologizing definition of homosexuality in the USSR: on his exemption papers he is classified 7B, meaning unfit for service because of "psycho-pathology," with no explicit mention of Viktor's homosexuality. Franeta, Rozovye Flamingo, 115, 118, and 121. Viktor, interview, Novosibirsk, 1995. 
avoidance, while also revealing the crucial role played by family and friends in mediating legal and medical injunctions relating to homosexual desire.

Dimitri, born in 1943, told his wife about his homosexual desires after ten years of marriage. ${ }^{47}$ She wanted to keep their apartment for herself and reported him to the police. Dimitri's partner was arrested near the Bolshoi, a well-known homosexual meeting-place, and the police subsequently forced him to reveal Dimitri's identity. Fortunately, Dimitri's sister found out that her brother had been summoned to the police station. She persuaded him to come with her to the psychiatric hospital to avoid being charged under Article 121.

Egor, born in 1953, is the son of a senior Gosplan civil servant. ${ }^{48}$ At the age of sixteen, he agreed to be treated by psychiatrists to protect his father's reputation. Until the late 1980s, medical experiments were carried out on patients, including electric shock treatment. Egor's father insisted on the pathologization of homosexuality in order to maintain his family's respectability. Although he considered his son to be sick, he did not accuse him of immorality. The son invested fully in the identity of "patient" that was assigned to him, but did not feel at fault or guilty of any crime. Moral fault and criminal infraction were both inextricably linked in his mind. The patient identity Egor finally accepted did not stop him being called in to the police station in a murder case. He said this summons was particularly humiliating, even worse than being beaten up by the police in the public lavatories in the Leninskie Gory. The criminalization of homosexuality affected Egor when he was summoned for several interrogations by the Moscow department of criminal investigation (ugolovnyi rozysk moskovskii) because the investigators considered homosexuality to entail a predisposition towards crime, in this case towards homicide.

This contradictory definition of homosexuality, whereby one was supposed to suffer from pathology but nevertheless be criminally responsible (anti-sodomy article), brought the medical and legal authorities into competition when it came to legislation concerning homosexuality, and the doctors had the last word in the late Soviet period. Igor was born in 1952 and studied medicine at Krasnoiarsk. ${ }^{49}$ He explains that he was questioned by the police about his homosexuality and was afraid of being imprisoned. With the support he received from the medical faculty, and especially from a helpful female psychiatrist who diagnosed him as "mad," he escaped prosecution. ${ }^{50}$

From the accounts of my interviewees, what emerges is that both women and men experienced the pathologization and criminalization of homosexuality as forms of stigmatization. Whereas some men were able to use the first

47. The sociologist Elena Yurevna Rozhdestvenskaya gave me this six-page interview, which had been conducted within the framework of Master's (magistratura) research in sociology by her student Ksenia Komorova at the National Research University Higher School of Economics, Moscow, in 2014. It describes the major features of a long, eventful life story (1945-2014). 2011.

48. Egor, interview, Moscow, April 2014, following an informal conversation in spring

49. Franeta, Rozovye Flamingo, interview, Krasnoiarsk, 1995, 63-78.

50. From 1983 to 1986, Igor reports that 136 people were convicted of homosexuality in six major trials in Krasnoiarsk. Ibid., 69. 
definition against the second with the help of friends, colleagues, or family, the two together could be used against the same person. Homosexual subjectivities could be constructed in the face of stigmatization under either heading. This becomes clear from the account of one of the oldest men who told me their life stories: Vasilii, born in $1938 .{ }^{51}$ As a teenager looking for information, he found an article in his father's medical encyclopedia; he remembers that a homosexual was considered to be sick and if he did not want to be given treatment, he would be sent to prison. When he was a student, his mother reported him to the police to frighten him off, not to punish him. His brother later tried to send him to a psychiatric hospital, however, as a ploy to gain use of the family dacha. His mother refused to countenance such a measure, although she was convinced that her son was suffering from a mental illness. The selective character of the judgement of Vasilii's parents, both doctors, thus played an important role in shaping his destiny. They only seemed to follow one of the aspects of the official, contemporary definition of homosexuality as a pathology, without including the criminal aspect or the ideological condemnation of homosexuality, the latter strongly emphasizing social and environmental factors and downplaying illness (a bourgeois etiology), as the second Stalin-era edition of the Great Soviet Encyclopedia used until 1969 claims.

My sample of men who lived as homosexuals in the late Soviet period differs from Franeta's on at least one point: most of the men who agreed to tell me their life stories were from Moscow or St. Petersburg, where the pathologization of male homosexuality appeared to have been the first form of stigmatization that they experienced. In the case of Siberia, as Franeta's interviews show, people were more afraid of being jailed. Vladislav, born in 1941, sees things in these terms at least. He had an apartment in Moscow that became a major meeting-place for men of all ages in the 1970s and 1980s. As in the case of Polina (above), it was the very idea of having his homosexuality made public and being subject to moral judgments that tortured Vladislav. In both cases, such exposure would be a threat to their secure professional identity and careers. He was not acutely concerned about the criminalization of homosexuality because, unlike in the provinces, Article 121 was applied "in two cases: when it was criminal (kriminal), in other words, when it involved minors. Generally this was in exceptional cases. ... Otherwise, there was a second variant that concerned dissent and was associated with political issues. Then they used that article." ${ }^{52}$ However, he said that the risk of criminalization aroused in him the fear that his "homosexuality would be made public." ${ }^{3}$ Fear of oglaska, the publicity given to his homosexuality, is what most disturbed him. He explained further: "In the provinces.... there were cases in which homosexuals [not pedophiles] were imprisoned. But that was in the provinces. There was none of that in Moscow. Nothing like that ever happened to any of my acquaintances. ${ }^{~} 54$ Like Polina, Vladislav did not want

51. Vasilii, interview, Moscow, June 2011.

52. Vladislav, interview, Moscow, June 2014.

53. Ibid.

54. Ibid. He explained to me how he understood this term: essentially, the fear that one's homosexuality would be made public derived from the fear of moral judgment ("moral'noye osuzhdeniye"). 
to be mixed up in any way with the criminal world. He totally condemned pedophilia, with which homosexuality was associated in the USSR. The pedophile, too, was both a criminal under the law and sick according to psychiatry, and thus was punished more severely than the homosexual in the USSR.

While we cannot generalize for the provinces, we may rethink the role played by pathologization and criminalization for both men and women expressing homosexual desire in the late Soviet period in Moscow and Leningrad. It was the confrontation with both persecutory mechanisms that encouraged forms shared by male and female homosexual subjectivities to emerge. The assertion that some were subject to imprisonment and others to psychiatric internment must thus be nuanced.

More generally, the historian Alain Blum has shown that "what was social departed from what was political" as a result of resistances he identifies mainly in sexuality and family life. ${ }^{55} \mathrm{~A}$ research pathway opens here concerning the role that the family played for these men and women. It cannot be reduced to a repressive function; nevertheless, major differences remain, particularly in the stricter allocation of roles to women (to be a wife and mother) and the greater sexual autonomy that men could enjoy. Vasilii's family circle displayed both solidarity and stigmatization. Furthermore, families might respond in diverse ways to repression by law or medical science that followed such stigmatization. Even in those cases where families assented to the pathologization or criminalization of homosexuality, a range of strategies may have been employed in negotiating their application. In Vasilii's life story, the family operates as a channel between medicine and the police, bringing home the reality of stigmatization within the context of a daily persecution while falling short of demanding imprisonment or internment in a psychiatric hospital. Sometimes family members refused to play the role of go-between at all.

In the USSR, as in most of the countries where homosexuality was criminalized, the anti-sodomy applied only to men who engaged in homosexual activity, which contributed to making female homosexuality invisible. Yet despite the differential allocation of gender roles and the binary nature of the medico-legal discourse in response to this allocation, there is a shared resonance to the way in which a number of men and women perceived their stigmatization. They express a common fear of being criminalized while coming to an understanding of their homosexual subjectivities in confrontation with the stigmatization of homosexuality.

\section{Soviet Homosexual Subjectivities Centered on Language, Irony, and Solidarity}

Having established that it is possible to speak of forms common to the homosexual subjectivities forged by both men and women, we may turn now to the task of outlining some of these forms. It should be noted from the outset that we are dealing with specifically Soviet subjectivities, the existence of which the work of Yurchak makes clear. He notes the term obshchenie, a culture of speech shared with "one's own people” (svoi). These terms enabled speakers

55. Alain Blum, Naître vivre et mourir en URSS, 1917-1991 (Paris, 1994) : 22 and 159-208. 
to position themselves both "within" and "outside" (vne), with one's own and outside a fixed official discourse, although to assume the latter position did not necessarily entail refusing to re-appropriate such discourse. The initial dualism suggested by Soviet-era language could be transcended. It was in fact possible to give a personal inflection to official discourse in such a way as to strike a balance with Soviet values; for example, by giving official discourse a personal slant via appeals to the official Soviet values of solidarity and friendship, a strategy adopted by my respondents.

Olga Krauze, for example, calls the men and women who expressed homosexual desire in the late Soviet period svoi, "her people" or nashi, "our people," stressing in this way the feeling of a common belonging that the 1990s would later weaken, as post-Soviet societies were atomized by economic crises that upset existing solidarities. Another term recurs in the discourse of the men and women who told me their life stories: they used the expression byt' $v$ teme for themselves, literally "on topic, in the know," equivalent perhaps to Marcel Proust's "en être," "one of us." This expression attests to a self-understanding held in common by Soviet homosexual subjectivities: it communicates a sense of "belonging," of having the same "knowledge;" of sharing it and having been initiated into it. More generally it belongs to a language typical of the late Soviet period and was also used in other areas: someone keen on science fiction might recognize someone else as "one of us" because they were "in the know" ( $v$ teme). Laurie Essig and Aleksandr Kondakov emphasize that the words tema and nashi, still in use in Russia, are located outside the framework of heteronormative culture. ${ }^{56}$ Stella notes that tema is a "non-gendered collective term for non-heterosexuals." ${ }^{\text {"57 }}$ It is therefore possible to conceptualize homosexual subjectivities without making the gendered distinction seen in contemporary Russian, where gay refers to men and lesbian to women. ${ }^{58}$ The Soviet-era terms goluboi (literally sky-blue) for homosexual men and rozovaia (literally pink) for homosexual women both referred to pastel colors as if to express the sense of sharedness replaced after the collapse of the USSR by a heightened specialization.

The intentional vagueness of the expression " $b y t$ ' v teme" allows for a surreptitious reference to one's own, enabling individuals to recognize each other without giving themselves away. In that sense, it may be compared with the term used by African-American gays and lesbians in the first half of the twentieth century, "in the life," which they shared with other marginalized Black groups (prostitutes, gamblers, and others). ${ }^{59}$ Following Essig, Stella notes that "terms such as goluboi, rozovaia, tema, and nashi" are "euphemistic and

56. Essig, Queer Russia, x, 197; Laurie Essig, “Serdtsa geev nado zaryvat' v zemliu: Razmyshleniia ob okhote," in Kondakov, ed., Na pereput'e, 11; Aleksandr Kondakov, "Formirovanie kvir-arkhiva issledovanii seksual'nostei," Kondakov, ed., Na pereput'e, xv-xvi.

57. Francesca Stella, Lesbian Lives in Soviet and Post-Soviet Russia, 6.

58. In Russia, this term "gay" denotes a negatively loaded otherness: the west. See: Baer, Other Russias, 6. A vocabulary for the late Soviet period has been compiled by Vladimir Kozlovskii, Argo russkoi gomoseksual'noi subkul'tury: Materialy kizucheniiu (Benson, VT, 1986): 119-46.

59. George Chauncey, Jessica Shatan, Archie Ferguson, and Vicki Gold Levi, Gay New York: Gender, Urban Culture, and the Making of the Gay Male World, 1890-1940 (New York, 1994), 28 and 312. 
ambiguous." "6o If Essig gives a positive "queer" interpretation of such terms, Stella, in her designation of women in their lived experience of homosexual desire, chooses to use a negative form: "non heterosexual." Unlike the usual taxonomies, the absence of any pejorative connotation and the open-ended meaning provided by the two expressions byt' $v$ teme and svoi/nashi, as used by men and women, show that a positive definition is possible, one that brings together some common forms of homosexual subjectivities capable of adopting collective Soviet values while seeking to go beyond its gender roles, characterized by "gender conventionalism." 61

\section{Solidarity and the Common Forms of Homosexual Subjectivities}

The women and men expressing same-sex desire might never cross each other's paths, although if they did meet, they could devise strategies for surviving together in shared secrecy. Without previous arrangement by one of those amazing chances that word-of-mouth makes possible, I held an interview in Moscow (July 2014) with Vadim (born in 1955), who told me of the family he formed with Ekaterina in the latter half of the 1970s: "There was a man working in the [young pioneers' summer] camp, his wife was with Ekaterina, and I was with him.... We made up one family. ... And we've been friends since."62 Ekaterina told me: "There was a couple, a husband and wife. Vadim was the husband's lover and I was the wife's. And we lived as a foursome in their place. There was their daughter Evgeniia. And all four of us brought the little girl up. We each took turns, as they say, to babysit her and read her fairytales at night." 63

This example illustrates a field of possibilities that may appear improbable, but which existed as a response, an adaptation to a hostile outside world; the essential point was that in the eyes of neighbors, one's family and one's workmates, a married couple with a child lived in the apartment with a young couple who were family friends. Note these people's agency, admittedly reduced to silence, but still able autonomously to reconstruct interactions by re-appropriating what it meant to be a family in the USSR; for example, reading fairytales to one's child at night, a highly valued practice in a state for which literature was the main tool in the moral development of children. On a number of occasions, I was told of this re-appropriation of marriage where a man and a woman expressing homosexual desire decided to marry to get an apartment and enjoy freedom of action without needing to hide from their husband or wife. ${ }^{64}$ One shared feature highlighted by both the men and women I interviewed was the invention of their own form of humor in the face of adversity.

60. Stella, Lesbian Lives in Soviet and Post-Soviet Russia, 46.

61. Rotkirch, The Man Question, 132-33.

62. Vadim (born in 1955), interview, Moscow, July 2014.

63. Ekaterina (born in 1954), interview, Moscow, July 2013.

64. Kozlovskii has published an interview he held with a homosexual man and a lesbian who got married in the early 1970s “as a cover” (dlia prikrytiia). See: Kozlovskii, Argo Russkoi Gomoseksualnoi Kultury, 211-28. 


\section{Laughing at Gender Roles to Create a Homosexual "Us"}

In Olga Krauze's interview and autobiography, she explains how she was introduced into homosexual circles of women and men. In her interviews, she stresses the importance of the gender roles that enabled homosexual men and women to recognize each other from the late 1960s to the late Soviet period in the 1980s.

In her last interview, she says that in the late 1960s she had a job working in the gardens at Catherine Palace, a homosexual cruising area. She was then living with a partner. She had short hair and, as she said to me, looked "masculine." She thought at that time that she and her partner were the only people in the world living that way, as if, she said, they were "on another planet." 65 Some homosexuals in the cruising area thought she was a man and offered to help her with her gardening work. At the time, she did not understand why they were interested. Not having been introduced to homosexual circles, she could not "see" it, as she put it; in other words, she was not "in the know."

In her book, she describes the time she went to the Hermitage Museum to see the statue of the Sleeping Hermaphroditus in a desperate attempt at finding her identity. As she stood there sunk in thought, two men were exchanging rings to seal their union. Noticing that she was alone, they invited her to join them, thinking she was one of them. ${ }^{66}$ This scene of initiation is naturally a reconstruction, but it is significant: she accepted her homosexual desire when men introduced her into homosexual circles. The core element of belonging relates to shared sexual orientation. The role of "boy" belonged to either sex as long as it remained in the register of homosexuality.

In her July 2014 interview, she describes how a young man approached her in the metro. He was a good-looking man of "Asian type," as she specified. During their conversation, she realized that this was a "boy" (mal'chik) like her; in other words, someone who played the "active" role as she put it. Through this woman, she discovered homosexual circles where women and men met. Once again, although in different terms, an initial misunderstanding once again served as the basis for a feeling of belonging shared by the two women.

She also describes how she met her male friend Vania, who was imprisoned under Article 121 in the 1980s. Olga Krauze was in a car with two friends. "A guy was walking past, wearing a woman's coat and make-up. I grabbed him by the coat and pulled him into the car (we had a girlfriend with us) and I said, 'Come here, handsome, I'll show you how to be feminine.' And he burst into tears so I said, 'Stop that, we're all our sort (svoi) here, we're going for a drive!' [She laughs.] And so our friendship started." ${ }^{67}$ Here was a young man who misunderstood. He was recognized as "one of us" by Olga Krauze, who played the part of go-between herself.

Olga Krauze freely plays with gender roles, assuming an attitude of frivolity towards the strict boundaries that they impose so as to escape the

65. Interview with Olga Krauze, Moscow, July 2014, following an informal conversation in January 2010.

66. Olga Krauze, Otpetaia zhizn', 84.

67. Interview with Olga Krauze, Moscow, July 2014. 
naturalizing logic of gender roles to which she refuses, like here friends, to conform. Precisely by bringing out the different forms that male and female homosexual subjectivities may take, she enables what they share to come to the fore. Her laugh, by opening a distance between herself and any specific gender role, allows her to both grasp a subjectively experienced freedom and attain a vantage point from which an affinity comes into view, and a common experience of homosexuality is affirmed. All sorts of tactics may be employed in saying aloud and asserting the common forms that homosexual subjectivities were capable of assuming. In the philosopher Judith Butler's analysis of drag as "gender performance," she reconstructs the different ways in which individuals play with gender roles, while conceding to such play no power to fundamentally challenge these roles. ${ }^{68}$ We may observe that in the examples I have chosen, all are playing gender roles that do not conform to the behavior expected of the opposite sex. Without speaking of subversion, it is possible to detect here resistance to gender categorizations. Olga Krauze's stories are studded with camp irony, as are Nikolai Baev's. ${ }^{69}$ In particular, he mentions a term that Soviet-era homosexuals used to describe a form of humor specific to themselves. This is khabalstvo: "a way of presenting oneself as feminine, effeminate. When, for example, a gay man starts speaking of himself as 'she." 70 Baev has met men who continue to use this humor. I find a similar irony in a biographical account published in French by Sergey Kondrashov, born in 1972, which is also set in Siberia. He claims for himself the gender roles conventionally attributed to women to explain slightly lower school results "in sport, civil defense, and labor law, typically male subjects that a conspiratorial (zakonspirirovannaia) girl like me silently and secretly detested." 71

Even if it is found elsewhere, Nikolai Baev suggests that this play on self-derision represents a form common to Soviet-era homosexual subjectivities. It belongs to the Soviet era because the use of khabalstvo, he points out, is declining in today's Russia. According to the sociologist Arnaud Lerch, "Salient cultural features of gay culture such as the high value placed on 'camp'-which is a particular form of aesthetics, sarcasm, and humorous parody-are probably connected to the historical need for secrecy. The use of insinuation and innuendo for mutual recognition and communication in public spaces, the distancing from ordinary social roles caused by being 'in

68. "As much as drag creates a unified picture of 'woman' (what its critics often oppose), it also reveals the distinctness of those aspects of gendered experience which are falsely naturalized as a unity through the regulatory fiction of heterosexual coherence. In imitating gender, drag implicitly reveals the imitative structure of gender itself-as well as its contingency." Judith Butler, Gender Trouble: Feminism and the Subversion of Identity (New York: 1990), 175.

69. Nikolai Baev (activist, born in 1974), interview, Moscow, July 2014.

70. For evidence of this and some analysis, see Dan Healey, "Comrades, Queers, and 'Oddballs': Sodomy, Masculinity, and Gendered Violence in Leningrad Province of the 1950s," Journal of the History of Sexuality 21, no. 3 (September 2012): 496-522.

71. Serge Kandrashov, Mes vacances de printemps: Voyage vers ma jeunesse et ses amours (Neuilly-sur-Seine, 2011). The Russian original Kondrashov, Sergei.vesennie.pdf was downloaded from his blog and retranslated, last accessed October 26, 2013. Here, p. 217. This source is no longer available online in the original, taken down by the author. 
the closet,' particularly by leading a double life, have generated in this way a particular cultural attitude towards the social world." "72 It can be seen, therefore, why my male and female interviewees, in using an updated camp irony, were perpetuating Soviet homosexual subjectivities.

This "particular cultural attitude" prioritizes the clandestine in response to a criminalized identity. It demonstrates how the stigma of felony associated with homosexuality could be turned around and re-appropriated. Olga Krauze describes the bonds that joined men and women expressing their homosexual desire in the late Soviet period: "We had a sort of state within the State, the way the Gypsies had theirs ... We had our mafia... We helped each other." ${ }^{73}$ Friendship was a key value for the Soviet regime, and some Soviet homosexuals used it to legitimize their relations. ${ }^{74}$ Her two interviews with me and her autobiography convinced me that Olga Krauze embodies certain Soviet-era values. ${ }^{75}$ This sense of shared belonging was repeated several times by Vasilii: "I think that gays are one people among all the peoples." 76 These spontaneous analogies to describe what united men and women who express same-sex desire highlight how much my interviewees harbored feelings of belonging under the model of a Soviet-era identity similar to those groups who in fact had no space of their own in the USSR-Mafiosi, Gypsies, Jewsbut were identified either by criminal record or by the nationality recorded in their passports. My Russian interviewees turned out not to have any intermediate identity resources such as national or religious feeling, causing them to identify more directly with the State, a State that was overtly atheist. In other words, it was not Russian nationality but Soviet citizenship that conflicted

72. Jean-Philippe Cazier, interview, "Sociologie de l'homosexualité," on the latter's blog on the French participatory news website Médiapart at http://blogs.mediapart.fr/ edition/bookclub/article/260713/sociologie-de-lhomosexualite (last accessed December 17, 2017).

73. Olga Krauze, interview, Moscow, Summer 2014.

74. One example is the song "Druzhba" (Friendship) by the famous tenor Vadim Kozin (1903-1994), who was imprisoned at the end of the war under Article 121. This 1930s song could be understood as a romantic homage to love between men, because its first verses speak of closeness, "a tender, caressing glance," the invitation to hold hands and "live together forever." Dan Healey has dedicated a chapter to the diary of Vadim Kozin in his Russian Homophia From Stalin To Sochi, 73-89.

75. Born in the year of Stalin's death, she spent her childhood crossing the entire Soviet Union because of her father's job and then spent her adolescence in eastern Ukraine. She tells of men in the street just out of labor camps. In general, there was a resurgence of "banditry" after World War II and the release of many camp inmates, which was not always welcomed in Soviet society. And yet there was an "idealization" of this world, particularly in the song genre known as blatnaia pesnia, "rogues' songs:" the criminal is seen in them as an authentic, solitary, free spirit who refuses laws that are not his own. This is the context for the terms "mafia" and "Gypsies" which she uses to designate homosexual men and women. Although abortion was legalized later under Khrushchev, the new penal code in 1960 maintained the Stalinist criminal offence of sodomy. Healey's explanation is that the release of 4.5 million camp inmates was a source of anxiety for the regime, which feared a generalization of homosexual behavior. See: Healey, Homosexual Desire in Revolutionary Russia, 239. See also Miriam Dobson, Khrushchev's Cold Summer: Gulag Returnees, Crime and the Fate of Reform after Stalin (Ithaca, 2009).

76. Vasilii, interview, Moscow, June 2011. 
with their homosexual desire. The only way that feeling Russian was ever expressed in my interviews was as a negation of Jewishness.

\section{Soviet and/or Russian Identity versus Homosexual Subjectivities?}

Even if Soviet Identity excluded any homosexual identity, as in the case of national belonging, homosexual subjectivities could appropriate one form of this Soviet identity: the soviet ethos of secrecy. ${ }^{77}$ Homosexuality could be seen as treason against the Soviet motherland. That is what emerges from Egor's account. ${ }^{78}$ He began to "be aware that the world would not accept [him] ... at the age of thirteen." As if to keep his past at a distance, he uses the second person singular: "It's an awful feeling, when you think that you are living in the best of all possible worlds, that like your country you have all your future before you, and suddenly you realize and you read [like many homosexual men and women, he read the article on homosexuality in the Great Soviet Encyclopedia] that you are either mad or a criminal."79 As a teenager he discovered his sexuality in cruising areas: "In the Leninskiye Gory park, there were cruising areas, big public lavatories near the entrances.” Frequenting such places tormented him, because he "wanted to love" and he "was disgusted by it." ${ }^{80}$ He explains further: "I felt that I wasn't like that, that I was forced, it seemed [he struggles for words] that I was a young man living at home, in his motherland, and so I had to get rid of it, this [homosexual desire] izgnat' (expel it)." ${ }^{\prime}$ These two excerpts show how patriotic feeling, a feeling of belonging to a motherland, conflicted with homosexual desire, identified as a crime or a sickness.

Jewish identity and homosexuality could both be concealed in the same family in what I call a Soviet ethos of secrecy. A wave of State antisemitism was unleashed after the Six-Day War, which resulted in the erecting of barriers to Jewish access to university. ${ }^{82}$ When speaking about his intention to leave for Israel, Yuri, born in 1969, mentioned that his father was Jewish and described antisemitism in the USSR:

They lived at a time when Jewishness wasn't the flavor of the month. So he carefully hid the fact that he was a Jew. At least, he made no show of it. And his name was David X [Jewish-sounding last name]. In conversation, he used the name David Borisovich.

77. I use this term as it is defined by Roland Barthes, a semiotician whose thought resists all essentialization. He saw ethos as "the character traits which the orator must show the public (his sincerity is of little account) to make a good impression: these are his 'airs' ... the orator gives a piece of information and at the same time says: I am this, I am not that." Roland Barthes, "Communications, no 8." (Paris, 1966) in The Semiotic Challenge, trans. Richard Howard, (New York, 1988), 74.

78. Egor, Interview, Moscow, April 2014. See Note 48.

79. Ibid.

80. Ibid.

81. Ibid.

82. Sarah Fainberg, Les discriminés: L'antisémitisme soviétique après Staline (Paris, 2014). 


\title{
AC: He didn't change his family name?
}

No, he didn't. He would introduce himself that way, when he met people, he didn't have to show his passport every time. He changed his name by using his patronymic. And for his children ... he put "Russian" for each of them, because in those days they entered the nationality in your passport. ${ }^{83}$

Then Yuri makes himself clear. “As for me, I'm Russian, period,” but he realizes that in his story he has given good reason to hold a negative image of the Soviet era, for which he was nostalgic after all. He therefore corrects himself by talking more colloquially in an attempt to sound more convincing:

\begin{abstract}
My grandfather didn't make a show (afishiroval) of it, he didn't hide it, he didn't conceal himself, no, he just didn't make a show of it. Because he was married to a Russian woman. That was not approved of by the Jews. He was mostly afraid of that, of having half-blood children. It was disapproved of by the Jews, but not by the others. For the Russians, it's all the same to them who you live with, who you mix your blood with. Personally, as a Russian, I couldn't care less. Maintaining the purity of the nation . . . that's not something the Russians want. ${ }^{84}$
\end{abstract}

Russianness was thus a way of distinguishing oneself from Jewishness, but Yuri says no more. He does proudly claim an identity: "I consider myself to be a Soviet person." Born in a closed city in Central Asia, now living in a town in the "red belt" of Russia, where the Orthodox Church is highly influential, the military education which his father gave him had a lasting impact on his behavior and outlook. His way of life is marked by secrecy, what he calls a "closed regime." Like others, he learned that homosexuality had been criminalized when the law was repealed, showing that he had internalized the ban to such an extent that it was no longer necessary to explicitly formulate it. Consequently, Yuri refrained from actively seeking out knowledge so that he might not infringe his ethos of vigilance and discretion. He took no personal initiative to learn more about his homosexual desire, which he only expressed during his professional travels. None of his friends or family know of his homosexuality. His way of referring to homosexuality uses the consensus vocabulary for the matter in Russia: he says gomoseksualist and gomoseksualizm to maintain the deviant connotations these words have, rather than adopting the words gomoseksual and gomoseksual'nost' that I used in interviewing him. Before the interview, he told me that he and his partner agree that homosexuality is not "normal." During the interview he repeats this, saying that "it is not the norm." He conforms here to a consensus discourse characteristic of contemporary Russian society, which is imbued with a Soviet ethos: "If a person is of a non-traditional orientation, no one will touch you

83. Yuri, interview, March 2015, a town in the "red belt" of Russia. Nearly half my Russian respondents mentioned their Jewish roots, without necessarily claiming to belong to the intelligentsia. Yuri was one of them. In a hesitation similar to that observed in the context of their same sex desire, they also frequently avoided describing their Jewish roots in terms of identity, an interesting bias that may explain how Jewish roots may clash with Russian as same-sex desire may clash with Soviet identity.

84. Yuri, interview, March 2015, a town in the "red belt" of Russia. 
or assault you. But if you say it openly and ... show off (afishiruesh), exhibit it all over the place, your non-traditionalness. Then you'll have problems. Big problems." 85

These are the same terms he uses to indicate that his father did not show off his Jewishness, that he indeed "concealed" it, even if he later rejects this choice of words. He certainly continues to employ such language when referring to himself: " $\mathrm{X}$ is not a big city, everything is seen. Especially in the case of personalities like me. It would be hard for me to hide in X." 86

Both grandfather and grandson choose to pass. ${ }^{87}$ Passing is stated to be a survival strategy informed by a principle of respectability, of what constitutes decent, proper behavior. The grandfather hid his Jewishness just as his grandson hides his homosexuality; a family trait is thereby handed down. This trait is symptomatic of the internalization within families of a Soviet ethos of secrecy, an ethos which made it possible to conceal any Otherness, whether "national" or "sexual," and at the same time to take on Soviet identity.

In the view of Anna Temkina and Anna Rotkirch, the Soviet State was always the "main actor in the formation of gender relations." 88 The present article adopts a different perspective, one from which the pertinence of the study of late Soviet homosexual subjectivities comes into view. From this perspective, we are also better placed to appreciate how the social elements may gain independence from the political elements of these subjectivities, when people who expressed same-sex desire during the late Soviet period deployed "resourcefulness" and "creativity." ${ }^{89}$ Although criminalization and pathologization of same-sex desire served to render it invisible, Stella notes that "this sheltered individuals involved in same-sex practices from public scrutiny." She adds, "Remaining invisible and unnamed had costs . . . however, staying under the radar also provided a degree of freedom." ${ }^{\circ 0}$ It is this freedom, albeit restricted, which made possible the common forms through which men and women lived their subjectivities. Highlighting such commonality, it should be stressed, does not entail dismissing the differences in same-sex desire in its gendered varieties or the relevance of pursuing distinct sociologies and histories of male and female homosexualities in Russia and elsewhere.

The present article seeks simply to challenge the overly binary representation that prevails in current scholarship of the persecution of homosexuality informed by medico-legal discourse, according to which certain persecutory mechanisms concerned men (criminalization) and others women (pathologization) exclusively. Such a dichotomy is not always appropriate

85. Ibid.

86. Ibid.

87. "Because of the great rewards in being considered normal, almost all persons who are in a position to pass will do so on some occasion by intent." Erving Goffman, Stigma: Notes on the Management of Spoiled Identity (New York: 1963), 74.

88. Anna Temkina and Anna Rotkirch "Soviet Gender Contracts and Their Shifts in Contemporary Russia," Idäntutkimus: Finnish Journal of Russian and Eastern European Studies 2 (1997): 6-24.

89. Rose-Marie Lagrave, ed., Fragments du communisme en Europe centrale (Paris, 2011), 12-13.

90. Stella, Lesbian Lives in Soviet and Post-Soviet Russia, 134. 
for understanding how some women and men arrived at an understanding of themselves as subjects of their sexuality in the face of shared stigmatization. By comparing sources, both primary and secondary, oral accounts and autobiographies, I have shown how some women and men arrived at an understanding of themselves in the face of this stigmatization and how they thereby expressed subjectivities that attest to a shared self-understanding. The common forms of their homosexual subjectivities are first expressed in isolation, as though Soviet homosexuals lived "on another planet," to use the words of Olga Krauze, because of a "conspiracy of silence," as Igor' Kon puts it. ${ }^{91}$ In some cases, the isolation is broken through the encountering of peers, whether men or women. Lacking a social identity or a community, some men and women who expressed same-sex desire did, however, articulate some forms held in common by Soviet "homosexual subjectivities," which I have shown were possible and which can also be defined positively. Shared laughter, language, and solidarity were just some of their expressions. They can be understood as characteristically Soviet subjectivities: they adopted Soviet values, while nevertheless seeking to escape the confines of gender or nationality categorizations. They were also Soviet in their internalization of selfcensorship, in what I have called a "Soviet ethos of secrecy."

An interviewee, who otherwise exhibits little affection for the Soviet regime, portrays the commerce surrounding public urinals in these-subjective-terms as a Soviet practice, even if in actual fact it was not confined to this regime. The perception of a shared self-understanding, uniquely Soviet in character, likewise informs his understanding of the painful introduction in Russia of a market economy which had impoverished many of his generation: born in 1938, he is fond of remembering the significant cultural and social fluidity of the USSR, which he could no longer perceive during the nineties, a period characterized rather by its spirit of exclusion. By way of example, he mentions the recent opening of clubs whose entrance fee is often prohibitively expensive; in contrast, "at least the toilets were for everyone."92

91. Kon, Seksual'naia kul'tura v Rossii, 176.

92. Vasilii, interview, Moscow, June 2011. See also Kārlis Vērdiņš, "Queer Male (Post) Soviet Narratives in Interviews by Rita Ruduša and Fiktion by Klāvs Smilgzieds,” Interlitteraria 20, no. 1, (2015): 236. 